\title{
The Scripture of Filial Piety [Revealed] by Wenchang: A Bibliographical Study ${ }^{\star *}$
}

\author{
HU JIECHEN ${ }^{*}$
}

Yuelu Academy, Hunan University, Lushan Road (S), Yuelu District, Changsha, Hunan Province, 410082, China

Received: October 20, 2020 • Accepted: January 13, 2021

(c) 2021 The Authors

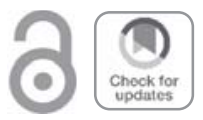

\section{ABSTRACT:}

This article discusses the date of the Scripture of Filial Piety [Revealed] by Wenchang (Wenchang xiaojing 文 昌孝經). The central claim of this contribution is that the Scripture appeared during the Ming-Qing transition, being a product of the ritualisation of the Classic of Filial Piety (Xiaojing 孝經). By examining more than twenty different editions, this article identifies at least three different lines of textual transmission, each connected to distinctive commentaries and reprints. Confucian literati were the main social actors responsible for the creation, reproduction, redaction, and annotation of the extant editions.

\section{KEY WORDS:}

The Scripture of Filial Piety [Revealed] by Wenchang; ritualisation of the Classic of Filial Piety; Wenchang cult; morality books; Confucian literati; Daoism; late imperial China

\footnotetext{
* Corresponding author. E-mail: hujiechen880831@hotmail.com

** This article is sponsored by the Chinese National Social Science Foundation (Guojia shehui kexue jijin 國家 社會科學基金, project No. 18CZJ020). I am very grateful to Vincent Goossaert and Daniel Burton-Rose for their extremely useful remarks on the final draft. And heartful thanks to my collegue and friend Bony Schachter, who read both the final and an earlier draft of this article and saved me from many mistakes. I would also like to thank the two anonymous reviewers of $\mathrm{AOH}$ for their insightful comments and suggestions.
} 


\section{INTRODUCTION}

The Chinese cult of Wenchang 文昌 has two historical origins. The first is the worship of an ancient constellation of the same name. The second is the cult of a local tutelary deity from Zitong 梓潼, in Sichuan 四川 I. ${ }^{1}$ Preserved in the Daoist Canon of the Ming period (Zhengtong daozang 正統道藏), the earliest extant texts devoted to Wenchang were supposedly produced during the Song and Yuan dynasties. ${ }^{2}$ Relying on these materials, scholars have reconstructed Wenchang's transformation from a local god into a national deity who is in charge of civil examinations, thus having control over the destiny of literati. ${ }^{3}$

Since the Daoist Canon preserves the majority of early Wenchang texts, most modern research was conducted from the perspective of Daoist studies. Many Wenchang texts of the post-Ming period, however, were actually produced as morality books (shanshu 善書) by Confucian literati (Hu 2020). Among them, the Scripture of Filial Piety [Revealed] by Wenchang (Wenchang xiaojing 文昌孝經, hereafter Scripture) survives in multiple Qing editions. Apart from circulating in separate volumes, this text was included in most Wenchang collections, including The Complete Works of the Divine Lord of Wenchang (Wendi quanshu 文帝全書, hereafter Complete Works). ${ }^{4}$ The editorial history of the Scripture shows that this text has been used as a ritual manual and as pedagogical material for elementary education. Among the morality books attributed to Wenchang, the number of its editions ${ }^{5}$ is arguably second only to the Tract on the Hidden Administration (Yinzhi wen 陰騭文, hereafter Hidden Administration). ${ }^{6}$ The text nevertheless remains largely neglected by modern scholarship. The few existent studies (Xiao 1997; Lan 2011; Zhan and Li 2017) of the Scripture offer but ahistorical interpretations of the notion of filial piety. Unfortunately, these studies do not pay attention to the Scripture's editorial history and lack philological rigour.?

In addition, these studies take for granted that the Scripture should be analysed as a Daoist text. Unfortunately, the same studies detach the text from its historical and religious contexts. In fact, instead of Daoist priests, it was the scholar-officials and local literati who identified as 'Confucianists' ( $w u r u$ 吾儒) who were responsible for the production and publication of the different editions of the Scripture. The answer as to why they published the specific text repeatedly and interpreted this Wenchang text as a 'Confucian' ( $r u$ 儒) scripture was hidden in its editorial history. A bibliographical investigation will help us to trace the very origin of the text and the religious context of its formation. In addition, the circulation history of the Scripture concerns both the

\footnotetext{
${ }^{1}$ On the prehistory and early history of Wenchang cult, see Kleeman 1994: 1-27, Gao 2008: 3-21.

2 On the Wenchang scriptures included in the Daoist Canon, see the entries contributed by Terry Kleeman, Isabelle Robinet, and Kristofer Schipper in the Taoist Canon (Schipper and Verellen 2004: 1203-1210).

3 On the expansion of Wenchang cult in Song and Yuan dynasties, see Morita 1984 and Kleeman 1993.

4 On the Wenchang collections in the Qing dynasty, see Goossaert 2015 and Hu 2020.

5 On the 'Kongfuzi', one of the most influential platforms for online auction of rare books in mainland China, there have been more than forty different editions of the Scripture auctioned in the last decade (www.kongfz.com, accessed 25 August 2020).

${ }^{6}$ For the general study of the Tract on the Hidden Administration, see Sakai 1957, 1999-2000: 509-544. It has also been introduced and translated into French by Vincent Goossaert (2012: 27-34) and into English by Terry Kleeman (1996).

7 For example, Xiao (1997: 17) and Lan (2011: 116) mistakenly read the name Qiu Jun 邱濬 as 'Ye Junzhong 耶沾 仲' and 'Qiu Junzhong 邱濬仲'.
} 
publication and the reception to this text throughout space and time. Therefore, the following examines the editorial history of the Scripture. ${ }^{8}$

This article examines more than 20 different editions housed in public libraries in China, Japan, the United States, Germany, and Australia. Demonstrating that Qiu Jun's 邱濬 preface (1421-1495) and Wang Ao's 王鏊 postscript (1450-1524) are spuriously attributed, I argue that the Scripture appeared as a product of the ritualisation of the Classic of Filial Piety (Xiaojing 孝 ( 經 $^{9}$, which was practised by the Confucian literati during the Ming-Qing transition. One of their hidden agendas was to create a more comprehensive 'Confucianism' by blurring its boundary with 'Daoism'. Additionally, this article discusses two other mid-Qing variants of the Scripture. These three lines of transmission, or variants, correspond to the creation of separate annotated editions, which in turn echoes the aforementioned motivation. Considering the fluctuating understandings of so-called 'Confucianism' ( $r u$ 儒) or 'Confucian teaching' (rujiao 儒教), it is necessary to point out that the terminology 'Confucian' or 'Confucianism' in this article is used in an emic way to refer to the self-identification of those literati rather than an etic category with a precise definition.

\section{TRACING THE ORIGINAL EDITION OF THE SCRIPTURE}

Recent studies of the Scripture focus on a six-chapter edition. As demonstrated in the present article, this edition in six chapters belongs to the earliest of the Scripture's three different lines of transmission. Xiao and Lan make use of a modern reprint included in the Extra-Canonical Daoist Works (Zangwai daoshu 藏外道書), which is the facsimile of the edition included in the New Edition of the Essentials of the Daoist Canon (Chongkan daozang jiyao 重刊道藏輯要, hereafter, New Edition). The New Edition offers the perfect starting point for the investigation of the textual transmission of the Scripture.

The New Edition was compiled in Sichuan during the transition from the Qing dynasty to Republican China. It includes over three hundred texts, which makes it the largest and most important collection of Daoist texts after the Ming Daoist Canon. It is also noteworthy that over a hundred texts included in the New Edition are absent from the Ming Canon so that the compilation is also one of the most valuable collections for modern scholars to investigate the religious texts produced in the late Ming and Qing dynasties. In the Daozang Jiyao Project, initiated by Monica Esposito (1962-2011), scholars have spent more than a decade scrutinising the New Edition and the different editions of its predecessor, the Essentials of the Daoist Canon (Daozang jiyao 道 藏輯要, hereafter Essentials). Esposito's research $(2007,2009,2013)$ clarified that Jiang Yupu 蔣 予蒲 (1755-1819), a high-ranking Qing official, initiated the editorial activities leading to the

${ }^{8}$ A recent study shows how the editorial history of a religious text will help the scholars to understand the motivation and religious identities behind the text (Schachter 2018).

${ }^{9}$ Some scholars use the English term 'scripture' to translate the Chinese term 'jing' books. For example, see the entry contributed by Daniel Overmyer and revised and expanded by Joseph Adler in the Encyclopedia of Religion (Jones 2015: 1580-1613). In this article, in order to differentiate the Confucian Xiaojing from the Wenchang xiaojing, I follow Lu Miaw-fen's translation and use the term 'classic' to translate 'jing' in the title of the Confucian Xiaojing since the former belongs to the 'Thirteen Classics' (shisan jing 十三經) in the Confucian tradition. Except for convenience reasons, the practitioners who ritualised the Confucian Xiaojing did regard the book as one of the most sacred texts. For the general study on the Classic of Filial Piety in late imperial China, see Lu 2011. 
publication of the Essentials during the Jiaqing reign (1795-1820). ${ }^{10}$ More recently, Kakiuchi Tomoyuki 垣內智之 and Ikehira Noriko 池平紀子 (2012) proposed the following sequence for the extant editions of the Essentials: 1) Nakanoshima exemplar 中之島本, 2) Tōyō Bunko exemplar 東洋文庫本, 3) Chengdu exemplar 成都本, 4) Jinbun exemplar 人文本, 5) Diet exemplar 國會 本. ${ }^{11}$

The Scripture ${ }^{12}$ was initially included in the third edition of the Essentials, i.e. the Chengdu exemplar (Kakiuchi and Ikehira 2012: 291), which was also the source-edition (diben 底本) of the New Edition. Therefore, the Scripture was included in the Essentials in the early nineteenthcentury; it was incorporated into the New Edition in the late nineteenth-century.

The four Wenchang texts ${ }^{13}$ included in the aforementioned Chengdu exemplar of the Essentials all offer the following signature 'respectfully collated by Zhu Gui [1731-1806], [styled] Shijun, from Daxing' (大興朱珪石君敬校). These four texts were almost identical to the texts included in the Anthology of the Divine Lord of Wenchang (Wendi shuchao 文帝書鈔, hereafter Anthology), also compiled by Zhu Gui. In addition, Zhu Gui himself revised and edited the Commentaries on Tract on the Hidden Administration, which proves that the Wenchang texts included in the Essentials originated from the Anthology. As discussed elsewhere (Hu 2020: 254-261), the Anthology was compiled in 1768 (Qianlong 33) as a concise edition of the Complete Works. Unfortunately, the original edition of the Anthology has been lost. The earliest extant edition of this work is a reprint of 1795 (Qianlong 60). This edition still predates the Essentials and supports the timeline mentioned above.

The recension of the Scripture included in the Complete Works originated from a 1735 (Yongzheng 13) reprint of the New Commentaries on the Scripture of Filial Piety [Revealed] by Wenchang (Wenchang xiaojing xinzhu 文昌孝經新註, hereafter New Commentaries). The author of these socalled 'new commentaries' was Tang Wanhuang 湯萬煌, who wrote them between 1707 and 1720 (Kangxi 46-59). Tang Wanhuang was from Changzhou county 長洲 in present-day Suzhou 苏州; he was probably a relative of Tang Chuanying 湯傳楹 (1620-1644). ${ }^{14}$ The Complete Works edition also includes a preface by Peng Dingqiu 彭定求 (1645-1719), dated to 1706 (Kangxi 45). ${ }^{15}$ Tang

10 For the relationship between the Essentials and Jiang Yupu, also see Mori 2001.

11 The editions are named after the libraries where they are housed, i.e. Osaka Prefectural Naganoshima Library, Tōyō Bunko (The Oriental Library), Sichuan Provincial Library (which is located in the Chengdu city), Jinbun Kagaku Kenkyūjo (Institute for Research in Humanities, Kyoto University), and the National Diet Library of Japan (Kakiuchi and Ikehira 2012: 274-285). It is noteworthy that the Diet edition was probably published in the Daoguang 道光 reign (1821-1850) rather than the Jiaqing 嘉慶 reign, see Maruyama 2015.

${ }^{12}$ It was entitled Scripture of Filial Piety of the Divine Lord of Wenchang (Wendi xiaojing 文帝孝經) in both Essentials and New Edition.

${ }^{13}$ The four texts were: Scripture of Filial Piety of the Divine Lord of Wenchang (Wendi xiaojing 文帝孝經), Precious Scripture to Save Humans from the Turning of the Kalpa Expounded by the Perfected Lord of the Great Dao of Original Sovereign (Yuanhuang dadao zhenjun jiujie baojing 元皇大道真君救劫寶經), Perfected Scripture of Wondrous Response for the Injection of Life and Leading-in of Progeny Expounded by the Perfected Lord of the Great Dao of Original Sovereign, the Responsive Transformation of Wenchang (Wenchang yinghua yuanhuang dadao zhenjun shuo zhusheng yansi miaoying zhenjing 文昌應化元皇大道真君說注生延嗣妙應真經), and Commentaries on the Tract on the Hidden Administration (Yinzhiwen zhu 陰騭文注).

${ }_{14}$ According to Wen Zhihua's research, Tang Chuanying had a half-brother named Tang Chuanxi 湯傳檄, who gained his juren 舉人 degree in 1642. Chuanxi had a son named Tang Wantun 湯萬㷚, who married You Tong's 尤侗 (1618-1704) eldest daughter (see Wen 2007: 13). Tang Wanhuang and Tang Wantun could be cousins, considering that their names were so similar and both of them were from Changzhou county.

15 For a recent study on Peng Dingqiu's participation in the local society, see Burton-Rose 2020. 
Wanghuang also mentions Peng Dingqiu in his preface. ${ }^{16}$ Since both were from Changzhou, I speculate that Tang Wanhuang used Peng's edition as the source-edition for his 'new commentaries'. According to Peng's preface, in 1706 a certain Cheng Ziyun 程子雲 from Xin'an 新安 produced a reprint in order to 'republish the old edition of the Side Commentaries on the Scripture of Filial Piety (Xiaojing pangzhu 孝經旁註, hereafter Side Commentaries) ${ }^{\prime 17}$. Therefore, the origin of the New Commentaries, which was the source-edition for the Complete Works edition, could be further traced back to the Side Commentaries produced no later than 1706. The following chart offers a reconstruction of the Scripture's textual transmission:

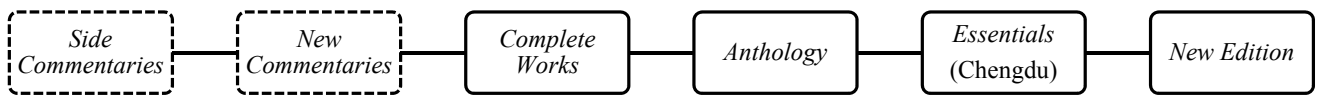

Neither the Kangxi edition of the Side Commentaries nor the Yongzheng edition of the New Commentaries is extant. In order to know to what extent the Complete Works edition preserved the contents of the New Commentaries, it is necessary to refer to other exemplars. Recently, I found a 1738 (Qianlong 3) reprint of the New Commentaries in Kyoto University. ${ }^{18}$ Comparing these two editions, I found that their respective paratexts are highly similar to one another. Table 1 below highlights their paratextual similarities and differences:

Table 1. Paratexts included in the two editions of the New Commentaries

\begin{tabular}{l|l|l}
\hline No. & Kyoto University exemplar (1738) & Complete Works edition (1743) \\
\hline 1 & Attributed to Qiu Jun, dated 1492 & Attributed to Qiu Jun, dated 1492 \\
\hline 2 & Attributed to Wang Ao, dated 1492 & Attributed to Wang Ao, dated 1492 \\
\hline 3 & Peng Dingqiu, 1706 & Peng Dingqiu, 1706 \\
\hline 4 & Tang Wanhuang, 1722 & Liang Xunmao 梁勲禁, 1735 \\
\hline 5 & Zhang Chendian 張陳典, 1728 & Tang Wanhuang, 1722 \\
\hline
\end{tabular}

Relying on the information above, I infer that the source-editions of the Kyoto University exemplar was a 1728 reprint, while the source-edition of the Complete Works edition was a reprint produced in 1735. These two reprints represent two different textual transmissions; both are later than 1722. Considering that these two extant editions are almost identical to one another, they may faithfully preserve the New Commentaries of the lost edition dated to 1722 .

The 1738 exemplar in Kyoto and the 1743 exemplar included in the Complete Works are the two earliest extant editions of the Scripture. Both editions trace back to the New Commentaries, dated to 1722 and now lost, the content of which is however preserved in the formers. Due to the lack of materials, we know very little about the even earlier Side Commentaries.

\footnotetext{
${ }^{16}$ According to Peng's biography, his eldest son Peng Shiqian 彭始乾 was married to You Tong’s granddaughter in Beijing in 1691 (Kangxi 30). See Nanyun laoren ziding nianpu 南畍老人自訂年譜 11a. Therefore, both Peng and Tang families were connected to You Tong's by marriage, not mentioning that all three of them were from Changzhou county. For the close relationship between Peng Dingqiu and You Tong, see Burton-Rose 2020.

17 Wendi quanshu, 1743 edition, 5.6b. It was also included in Peng Dingqiu's anthology. See Nanyun wengao, 12.1ab.

18 Wenchang xiaojing, 1738 edition.
} 


\section{REDATING THE SCRIPTURE}

The commentary in the New Commentaries was probably produced by Tang Wanhuang in the late Kangxi reign. The date of the commented text still remains unknown.

Any attempt at dating the Scripture will face the same challenges elicited by the Hidden Administration. On the one hand, no pre-Ming nor Ming texts, including the Daoist Canon, mention the Scripture. On the other hand, the Scripture provides no substantial internal evidence able to help us with establishing its date. In the preface attributed to Qiu Jun, Qiu claims that Zhen Dexiu 真德秀 (1178-1235), a famous neo-Confucian scholar-official in the Song dynasty, wrote some remarks on the Scripture. Furthermore, a reprint preface in the Complete Works claims that the Scripture was 'revealed in early Xiaozong reign' (1162-1189), during a spirit-writing séance devoted to Wenchang. ${ }^{19}$ Apparently, some Wenchang communities in late imperial China believed that the Scripture was produced as early as the medieval Wenchang texts included in the Daoist Canon. These assertions were probably made to endow the text with authority and sacredness. Modern scholars should not assume that the Scripture was produced in the Song dynasty. ${ }^{20}$

The Song-origin hypothesis can be disproven by a closer examination of the text. In the second chapter of the Scripture, there is a paragraph explaining how meritorious acts could be converted into merits for one's parents:

Saving people from difficulties is the same as if your parents had saved them. Aiding people in their emergencies is the same as if your parents had aided them. Commiserating with people's solitude is the same as if your parents were commiserating with them. Tolerating people's faults is the same as if your parents had tolerated them. ${ }^{21}$

救人之難，師是親救；濟人之急，師是親濟；憫人之孤，師是親憫；容人之過， 師是親容。

The four kinds of meritorious acts mentioned above trace back to the very beginning of the Hidden Administration, which was produced no earlier than the Ming dynasty. ${ }^{22}$ In other words, the Scripture obviously draws materials from the Hidden Administration. Consequently, its present redaction cannot be earlier than the Ming dynasty. Besides, in the medieval Wenchang corpus included in the Ming Canon, the texts are revealed to Wenchang by higher deities, including the Heavenly Worthy of Original Commencement (Yuanshi tianzun 元始天尊) and the Jade Sovereign (Yu huang 玉皇). ${ }^{23}$ The Scripture, on the other hand, is directly revealed and expounded by

19 See Wendi quanshu, 1743 edition, $5.8 \mathrm{a}-\mathrm{b}$.

20 As early as in the Qing dynasty, there were already some voices questioning this viewpoint of dating. Fang Bao 方苍 (1668-1749) argued that it was impossible that Zhen Dexiu prefaced the Scripture and the historicity of the paratexts attributed to Qiu and Wang was also questionable. See Wangxi ji 望溪集, 1851 edition, waiwen 外文, $4.4 \mathrm{~b}-5 \mathrm{a}$.

${ }^{21}$ See Wendi quanshu, 1743 edition, 5.28a.

22 On the dating of the Hidden Administration, see Sakai 1957 and Hu 2016.

23 The Wenchang cult became connected to the Heavenly Worthy of Original Commencement in the Song dynasty when the Wenchang version of the Scripture of the Great Cavern (Dadong jing 大洞經) was revealed (see Kim 2015). On the relationship between the Jade Sovereign and Wenchang and the rise of Jade Sovereign worship in early modern China, see Hsieh 2013, Schachter 2014, 2015. 
Wenchang. ${ }^{24}$ Moreover, the vernacular style of the Scripture is similar to the style of late imperial morality books, but it is not similar to the classical Wenchang texts of the Song dynasty.

Most editions of the Scripture include a preface attributed to Qiu Jun and a postscript attributed to Wang Ao (1450-1524), both dated to 1492 (Hongzhi 5). The historicity of both paratexts is, however, dubious. As mentioned above, both the 1728 and 1735 editions strictly follow the New Commentaries produced in 1722. In both editions, Qiu signed his preface as 'Master Qiu Qiongshan, taboo name Jun, style name Zhongshen' (邱璳山先生諱濬字仲深). Wang signed his postscript as 'Master Wang Shouxi, taboo name Ao' (王守溪先生諱鏊). Both authors sign in the third person, while other authors, including Peng Dingqiu and Tang Wanhuang, sign in the first person. Additionally, neither Qiu's nor Wang's anthology includes the aforementioned preface and postscript. Furthermore, the Hidden Administration, cited in the Scripture, was arguably produced in the late Ming, long after the period in which Qiu and Wang were active. For these reasons, I argue that Qiu Jun and Wang Ao did not author the paratexts attributed to them.

In order to demonstrate this point, we must examine the aforementioned paratexts in a detailed manner. Qiu's preface offers the date of 1492 and the personal title 'Ming Junior Guardian and Grand Secretary (明少保大學士). ${ }^{25}$ This is an anachronism. According to the History of Ming (Mingshi 明史):

In the $6^{\text {th }}$ year [of the Hongzhi reign, i.e., 1493], ...the Palace Steward Mao Cheng, the Censor Song De, and the Censor Zhou Jin memorialised the Emperor and impeached [Qiu] Jun, saying that he was not qualified for the position of minister. [But] the Emperor did not intervene. In the next year, [Qiu Jun] was invested as the Junior Guardian. He died in the eighth year [of the Hongzhi reign] when he was 76 years old. ${ }^{26}$

(弘治) 六年……給事中毛呈, 御史宋真、周津等交章劾浚不可居相位, 帝不 問。逾年, 加少保。八年卒, 年七十六。

Therefore, the historical Qiu Jun was not invested as Junior Guardian until 1494 (Hongzhi 7).

Similarly, in Wang's postscript, the date was the same, and his title was 'Ming Grand Mentor and Grand Secretary (明太傅大學士)' and 'installed as the Academician Reader-in-waiting in the Hanlin Academy (官內翰林侍讀學士)’. According to the History of Ming:

In the third year of the Jiajing reign [1524]... (Wang Ao) died when he was 75 years old. He was entitled after death as the Grand Mentor, and his posthumous title was Wenke 文 恪 (lit. literary and scrupulous). ${ }^{27}$

嘉靖三年復詔有司存問。未幾卒, 年七十五。贈太傅, 諡文恪。

\footnotetext{
${ }^{24}$ It is necessary to point out that, among the early Wenchang texts, the Book of Transformation (Huashu 化書) and the Esoteric Biography of Qinghe (Qinghe neizhuan 清河內傳) was expounded directly by Wenchang rather than higher deities. But from the perspective of genre, they were not scriptures but rather (sacred) biographies or, if we use Kleeman's (1994) words, 'a God's own tale'.

${ }^{25}$ The English translations of official titles in this article are basically adopted from Hucker's (1985) dictionary.

${ }^{26}$ Mingshi 181.5b-6a

${ }^{27}$ Mingshi 181.23a.
} 
Therefore, the historical Wang Ao did not achieve the rank of Grand Mentor in 1492, but rather in 1524 (Jiajing 3), after his death.

Thirdly, the anachronic title of 'installed as the Academician Reader-in-waiting in the Hanlin Academy' is the most important piece of evidence. ${ }^{28}$ According to the entry 'Hongzhi 8, 3/26' (i.e., 1495 April 20) in the Veritable Records of the Ming (Ming shilu 明實錄):

On the day of jiyou, (the Emperor) entitled Wang Ao, the Right Secretariat of the Heir Apparent and the Right Adviser in the establishment of the Heir Apparent, with the Academician Reader-in-waiting in the Hanlin Academy. ${ }^{29}$

己酉, 改右春坊右諭德王謷為翰林院侍讀學士。

Therefore, Wang Ao achieved this rank in 1495 (Hongzhi 8), not 1492 as claimed in the postscript.

The above proves that the historical Qiu Jun and Wang Ao did not author the paratexts attributed to them in the editions of the Scripture. It is nevertheless possible that they were revealed by Qiu and Wang through spirit-writing during the Ming-Qing transition, while their dates and titles were fabricated and added by later compilers. It is also noteworthy that such attribution is not arbitrary. The earliest extant editions of the Scripture, including the Side Commentaries and the New Commentaries, circulated mainly in the Suzhou area. Wang Ao was actually from Wu county (Wu xian 吳縣) in present-day Suzhou, while Qiu Jun was his instructor. Both were famous neoConfucian scholar-officials. Unlike Wang Ao, Qiu Jun was against both Buddhism and Daoism and regarded himself as a strict Confucianist. Therefore, Qiu Jun's endorsement could add more elements of 'Confucianism' to the Scripture. ${ }^{30}$

Additionally, the ritualisation of the Confucian Classic of Filial Piety (Xiaojing 孝經) during the Ming-Qing transition also informs the creation of the Scripture. From the late Ming onwards, Confucian literati such as Lü Weiqi 呂維祺 (1587-1641) and Xu Sanli 許三禮 (1625-1691) invented a series of ritual practices devoted to the Classic of Filial Piety and related to Wenchang. ${ }^{31}$ The core of Lü Weiqi's practice was to chant the Classic of Filial Piety:

I reverently believe in this Classic, [as much as I reverently believe in] Heaven, Earth, the deities, my parents, and my teachers. I spent twenty years pondering painstakingly and diving into the text repeatedly. I burnt incense whether during the morning or during the evening and respectfully chanted [the Classic] several times. ${ }^{32}$

愚敬信此經如天地、神明、父母、師保，二十年苦心玩索，沉潛反復，或晨夕焚 香, 恭誦數過。

28 The two aforementioned titles are the highest ones in Qiu and Wang's careers. Therefore, there are still very small possibilities that merely these two titles were added by the later compiler as an act of homage. However, the third case presented below is not the highest official title, which means the mistake is nothing but anachronism.

29 Ming Xiaozong jing Huangdi shilu 明孝宗敬皇帝實錄 98.10b.

30 On Qiu's attitude against the Buddhism and Daoism, see Lee 2005.

${ }^{31}$ Wang Fan-sen (1998) might be the first scholar who notices this unique phenomenon. Lu Miaw-fen (2008) further scrutinises more cases of ritual chanting, visualisation, and transcribing of the Classic of Filial Piety among the literati in the late Ming and early Qing and their common religious elements and different individual characteristics.

32 Xiaojing huowen 孝經或問, the Xuxiu siku quanshu edition, 1a-b. 
As a result, Wenchang appeared in Lü's dream and bestowed upon him divine treasures:

Master Lü burnt incense at night, chanted the Classic of Filial Piety several times, and then he nodded off. A deity resembling the Divine Lord of Wenchang [appeared] [...] The Divine Lord took out a book in one scroll from his sleeve and bestowed it upon Master Lü, saying: 'this volume records the esoteric knowledge of the Classic of Filial Piety.' Master Lü took a look at it; [the book] contained charts, inscriptions, talismans, and registers, all written with cinnabar. He paid obeisance and received it. ${ }^{33}$

呂子夜焚香, 誦《孝經》數過, 乃假寎。有神如文昌帝君者, ......帝袖中出文書 一卷賜吕子曰： ‘此與《孝經》相表裡。”吕子視之, 皆丹篆圖書符籙, 拜而受 之。

Xu Sanli's practice shared a similar feature. In his ritual of 'serving Heaven' (shitian 事天), it was mandatory to worship Wenchang and chant the Classic of Filial Piety ritually:

Beside [my house] there is a small building. A statue of Wenchang is venerated on its upper floor, while in the middle floor, there are the divine lots of Wenchang. Every morning and night, I imitate Master Shao (i.e. Shao Yong 邵雍, 1012-1077) and practice self-cultivation by 'reporting to Heaven' (gaotian 告天). On the first and fifteenth day of every month, I chant the Classic of Filial Piety. Sometimes I draw a divine lot, and they are always as precise as the echo. ${ }^{34}$

旁有一小樓, 上供文昌像, 中設文昌籤。每旦晚仿邵子告天做工夫, 每朔望誦《 孝經》, 間求一籤, 應皆如響。

Later, Xu developed this ritual into a new one named 'report to Heaven' (gaotian 告天) and practised it every day. One of the steps was to read six chapters from the Classic of Filial Piety. From these cases, we can see that both Lü and Xu were attempting to combine the Classic of Filial Piety with the Wenchang cult in these newly invented 'Confucian' rituals. ${ }^{35}$

The plain text of the Scripture was written in four-character-sentences with different rhymes. This made the text more suitable for chanting, at least in comparison with the Classic of Filial Piety. The Scripture's content emphasises that Heaven and Earth are the Great parents (天地為 大父母), which agrees with Yu Chunxi 虞淳熙 (1553-1621) and other literati's reading of the Classic of Filial Piety (Lu 2011: 179).

Except for the ritual chanting of the Classic of Filial Piety, other details showed that the practice of Lü and $\mathrm{Xu}$ was arguably inspired by Daoist rituals. For example, Lü burnt incense before the chanting, and $\mathrm{Xu}$ drew divine lots in front of the statue. They nevertheless related these practices to the concept of self-cultivation (gongfu 工夫) in a neo-Confucian way rather than mentioning its Daoist characteristics. Lü even received talismans and registers from the deity

\footnotetext{
${ }^{33}$ Mingde xiansheng wenji 明德先生文集, the Siku quanshu cunmu congshu edition, 10.1a-b.

34 Tianzhong xuzi zhengxue heyi ji 天中許子政學合一集, the Siku quanshu cunmu congshu edition, juanzhong 卷 中, dingsi wenda 丁巳問答, $3 \mathrm{~b}$.

35 A noteworthy detail was that the text Xu chanted in the ritual was six-chaptered rather than eighteen-chaptered. It was not certain whether it referred to the six chapters selected from the eighteen-chapter Classic of Filial Piety or the full text of the Scripture. Xu nevertheless mentioned elsewhere that he chanted the eighteen-chapter Classic occasionally. I am grateful to Prof. Lu Miaw-fen for pointing out this detail.
} 
in a dream and regarded them as 'esoteric knowledge' of a Confucian classic! This motivation to absorb some Daoist elements into Confucianism undoubtedly characterised the religious context of the formation of the Scripture.

\section{VARIANTS}

The editorial history of the Scripture attests to the appearance of two other variants. The first variant is the Qiqu 七曲 edition, compiled by Huang Zhengyuan 黃正元 (fl. 1713-1758) during the Qianlong reign. The second variant is a modified version received in a spirit-writing altar dedicated to Lüzu 呂祖 during the Qianlong reign. All three variants will be introduced and discussed below.

\subsection{The original edition of the Scripture}

In this version, Wenchang explains the importance of filial piety and expands its boundary from kinship to a much broader dimension, such as filial piety to the Heaven Father and Earth Mother as well as loyalty to the Emperor. The Scripture begins with a 'Sutra Opening gāthä' (kaijing ji 開經 偈) and concludes with several hymns (zan 讚). The main part includes six chapters, entitled 'Raising Children' ( $y u z i$ 育子), 'Embodying One’s Parents' (tiqin 體親), 'Distinguishing Filial Piety' (bianxiao 辨孝), 'Guarding the Body' (shoushen 守身), 'Teaching Filial Piety' (jiaoxiao 教孝), and 'Action [and Retribution] of Filial Piety' (xiaogan 孝感 ${ }^{36}$ ). The first chapter teaches the readers how to become aware of the love and care received not only from one's biological parents but also from the great Heaven Father and the Earth Mother. The second chapter is about being considerate of the parents and paying a debt of gratitude. The third chapter discusses the boundaries of filial piety. The fourth chapter persuades the reader to cherish and protect one's own body since it belongs to one's parents. The fifth chapter focuses on the vital role of the master ( $s h i$ 師) in the instruction of filial piety. The sixth chapter explains the salvific power of filial piety, which could protect practitioners from disease and disasters and even rescue the parents and ancestors from the samsāra, especially from the realms of 'terrestrial prisons' (diyu 地獄) and hungry ghosts, or preta (e'gui 餓鬼). Each chapter is attached with one or more gāthās (jizi 偈子) and incantations (zhou 咒): $:^{37}$

The opening gāthā and concluding hymns follow the style seen in traditional Daoist scriptures. The plain text, however, was written in a vernacular style rather than a classical one. Similarly, the incantations and other so-called gāthās scattered in the six chapters correspond to vernacular poetry and cannot be found elsewhere. These rhymed texts were probably designed for individual chanting. In addition, all extant editions follow the thread-bound (xianzhuang 線裝) format, which makes them reading devices or ritual items for private practice; they do not follow the sutra binding (jingzhe zhuang 經折裝) format, often used in Daoist or Buddhist ritual books.

36 The title of chapter six is quite confusing. But according to the content, gan 感 in the title is the abbreviation of the disyllabic word ganying 感應.

37 For a general introduction to the content of the Scripture, see the entry contributed by Terry Kleeman in the forthcoming companion to the Essentials and New Edition (Lai 2021). 
Table 2. The Content of the Scripture

\begin{tabular}{|c|c|c|c|}
\hline Chapter Title & Sections & Format & Number of Characters \\
\hline $\begin{array}{l}\text { Sutra Opening Gāthā } \\
\text { 開經偈 }\end{array}$ & & 5-character poem & 40 \\
\hline \multirow{3}{*}{$\begin{array}{l}\text { Chapter One: Raising } \\
\text { Children } \\
\text { 育子章第一 }\end{array}$} & $\begin{array}{l}\text { The main text starts with } \\
\text { 'The Perfected Lord said' } \\
\text { (真君曰) }\end{array}$ & 4-character prose & \begin{tabular}{l}
\multicolumn{1}{c}{572} \\
(the number does NOT \\
include the first three \\
characters 真君曰)
\end{tabular} \\
\hline & $\begin{array}{l}\text { Gāthā } \\
\text { 偈子 }\end{array}$ & Two 7-character poem & $56+28$ \\
\hline & $\begin{array}{l}\text { Divine Incantation of } \\
\text { Numinous Mercy } \\
\text { 靈慈神咒 } \\
\end{array}$ & dhāraṇi & 58 \\
\hline \multirow{5}{*}{$\begin{array}{l}\text { Chapter Two: } \\
\text { Embodying the } \\
\text { Parents } \\
\text { 體親章第二 }\end{array}$} & $\begin{array}{l}\text { The main text starts with } \\
\text { 'The Perfected Lord said' } \\
\text { (真君曰) }\end{array}$ & 4-character prose & 808 \\
\hline & $\begin{array}{l}\text { Gāthā } \\
\text { 偈子 }\end{array}$ & $\begin{array}{l}\text { Three } 5 \text {-character } \\
\text { poems }\end{array}$ & $30+50+90$ \\
\hline & $\begin{array}{l}\text { The main text starts with } \\
\text { 'The Perfected Lord said' } \\
\text { (真君曰) }\end{array}$ & 4-character prose & 164 \\
\hline & $\begin{array}{l}\begin{array}{l}\text { Gāthā } \\
\text { 偈子 }\end{array} \\
\end{array}$ & 5-character poem & 140 \\
\hline & $\begin{array}{l}\text { Mind Enlighting Precious } \\
\text { Incantation for the Filial } \\
\text { Children } \\
\text { 孝子明心寶咒 } \\
\end{array}$ & 7-character poem & 56 \\
\hline \multirow{3}{*}{$\begin{array}{l}\text { Chapter Three: } \\
\text { Distinguishing Filial } \\
\text { Piety } \\
\text { 辨孝章第三 }\end{array}$} & $\begin{array}{l}\text { The main text starts with } \\
\text { 'The Perfected Lord said' } \\
\text { (真君曰) }\end{array}$ & 4-character prose & 540 \\
\hline & $\begin{array}{l}\text { Gāthā } \\
\text { 偈子 }\end{array}$ & $\begin{array}{l}\text { One } 7 \text {-character poem } \\
\text { and four 5-character } \\
\text { poems }\end{array}$ & $56+30+160+60+20$ \\
\hline & $\begin{array}{l}\text { Subtleties Uncovering } \\
\text { Incantation for the Pure Filial } \\
\text { Piety } \\
\text { 純孝闡微咒 }\end{array}$ & 7-character poem & 28 \\
\hline \multirow{3}{*}{$\begin{array}{l}\text { Chapter Four: } \\
\text { Guarding the Body } \\
\text { 守身章第四 }\end{array}$} & $\begin{array}{l}\text { The main text starts with 'The } \\
\text { Perfected Lord said' (真君曰) }\end{array}$ & 4-character prose & 416 \\
\hline & $\begin{array}{l}\text { Gāthā } \\
\text { 偈子 }\end{array}$ & $\begin{array}{l}\text { Three 5-character } \\
\text { poems }\end{array}$ & $40+50+50$ \\
\hline & $\begin{array}{l}\text { Golden Body Incantation for } \\
\text { the Filial Children } \\
\text { 孝子金身咒 }\end{array}$ & 7-character poem & 28 \\
\hline
\end{tabular}




\begin{tabular}{|c|c|c|c|}
\hline Chapter Title & Sections & Format & Number of Characters \\
\hline \multirow{2}{*}{$\begin{array}{l}\text { Chapter Five: Teaching } \\
\text { Filial Piety } \\
\text { 教孝章第五 }\end{array}$} & $\begin{array}{l}\text { The main text starts with 'The } \\
\text { Perfected Lord said' (真君曰) }\end{array}$ & 4-character prose & 248 \\
\hline & \begin{tabular}{|l} 
Gāthā \\
偈子
\end{tabular} & $\begin{array}{l}\text { Two 5-character } \\
\text { poems }\end{array}$ & $40+20$ \\
\hline \multirow{6}{*}{$\begin{array}{l}\text { Chapter Six: Action } \\
\text { [and Retribution] of } \\
\text { Filial Piety } \\
\text { 孝感章第六 }\end{array}$} & $\begin{array}{l}\text { The main text starts with 'The } \\
\text { Perfected Lord said' (真君曰) } \\
\text { Part I }\end{array}$ & 4-character prose & 256 \\
\hline & $\begin{array}{l}\text { Gāthā } \\
\text { 偈子 }\end{array}$ & 5-character poem & 70 \\
\hline & $\begin{array}{l}\text { The main text starts with 'The } \\
\text { Perfected Lord said' (真君曰) } \\
\text { Part II }\end{array}$ & 4-character prose & 504 \\
\hline & $\begin{array}{l}\text { Divine Response Incantation } \\
\text { of Action [and Retribution] of } \\
\text { Filial Piety } \\
\text { 孝感神應咒 }\end{array}$ & $\begin{array}{l}\text { Two 4-character } \\
\text { poems and one prose }\end{array}$ & $32+40+121$ \\
\hline & $\begin{array}{l}\text { Gāthā of Writ Seal for the } \\
\text { Filial Children } \\
\text { 孝子文印偈 }\end{array}$ & 5-character poems & 120 \\
\hline & $\begin{array}{l}\text { Osmanthus Garden Heavenly } \\
\text { Fragrance Mind Seal Gāthā } \\
\text { for the Filial Children } \\
\text { 孝子桂苑天香心印偈 } \\
\end{array}$ & 7-character poem & 410 \\
\hline $\begin{array}{l}\text { Hymns } \\
\text { 讃文 }\end{array}$ & & Poems and proses & 531 \\
\hline
\end{tabular}

\subsection{The Qiqu edition of Scripture}

The full title of this edition is Old Edition of the Scripture of Filial Piety [Revealed] by Wenchang on Mount Qiqu (Qiqu jiuben Wenchang xiaojing 七曲舊本文昌孝經). It was supposedly produced in 1735 and included in the True Realm of Nature and Heaven (Xingtian zhenjing 性天真境) published in 1737 (Qianlong 2) by Huang Zhengyuan. Unfortunately, I have not found any extant copy of this original edition. The earliest extant edition is a reprint produced in 1837 (Daoguang 17). Exemplars of this edition may be found in the National Diet Library of Japan, the Bavarian State Library in Germany, and the Australian National University. ${ }^{38}$

Huang Zhengyuan was from Luoyuan county (羅源) in present-day Fujian province. He became a presented scholar (jinshi 進士) in 1713 (Kangxi 52). During his whole life, he compiled and published a considerable amount of popular morality books, including the Illustrated Commentaries on the Tract on the Hidden Administration (Yinzhiwen tushuo 陰鵱文圖說) and the Illustrated Commentaries on the Treatise on Retribution (Ganyingpian tushuo 感應篇圖說) (Yau 2005: 142-153).

38 They were different copies of the very same edition. The Japanese copy has the highest scanning quality but also several missing pages. Therefore, the text cited below was basically based on the Japanese copy and supplemented by the others when the page is missing. 
According to Huang's postscript, he obtained the six-chapters version of the Scripture from a friend in 1735 but was extremely dissatisfied with its divine incantations and gāthās, which he deemed as 'sounds from Buddhist classics and Sanskrit songs' (fodian fanbai zhi yin 佛典梵唄之 音). Therefore, he set up a spirit-writing altar and asked for revelation. The Divine Lord of Wenchang subsequently descended and

revealed to him the Old Edition [of the Scripture of Filial Piety Revealed by Wenchang] on Mount Qiqu. Not only the sounds from Buddhist classics and Sanskrit songs were completely deleted from this new edition, but also the six chapters, which were wrongly and forcibly added by later people, were rearranged. The bypast chaos was neatened at one blow. ${ }^{39}$ 示以七曲舊本。不但佛典梵唄之音概從刪刈, 並六章亦屬後人強合, 向之聚雜無 穢者, 一旦廓清。

Apparently, there were at least two significant differences between the Qiqu edition and the earlier one, namely, the deleted incantations and gāthās and the rearranged chapters. More specifically, the six chapters in the original edition were split into eighteen chapters in the Qiqu edition, listed as below:

Table 3. Comparison between the Two Varieties

\begin{tabular}{|c|c|}
\hline Original edition & Qiqu edition \\
\hline \multirow{5}{*}{$\begin{array}{l}\text { Chapter One: Raising Children } \\
\text { 育子章第一 }\end{array}$} & $\begin{array}{l}\text { Chapter One: The Foundation } \\
\text { 肇基章第一 }\end{array}$ \\
\hline & $\begin{array}{l}\text { Chapter Two: Giving Birth to Children } \\
\text { 生子章第二 }\end{array}$ \\
\hline & $\begin{array}{l}\text { Chapter Three: Protecting [the Children] } \\
\text { 保護章第三 }\end{array}$ \\
\hline & $\begin{array}{l}\text { Chapter Four: Educating [the Children] } \\
\text { 教育章第四 }\end{array}$ \\
\hline & $\begin{array}{l}\text { Chapter Five: The Common Acceptance } \\
\text { 同秉章第五 }\end{array}$ \\
\hline \multirow{6}{*}{$\begin{array}{l}\text { Chapter Two: Embodying One’s Parents } \\
\text { 體親章第二 }\end{array}$} & $\begin{array}{l}\text { Chapter Six: Rooting the Heart } \\
\text { 根心章第六 }\end{array}$ \\
\hline & $\begin{array}{l}\text { Chapter Seven: Attending and Pleasing [One’s Parents] } \\
\text { 承歡章第七 }\end{array}$ \\
\hline & $\begin{array}{l}\text { Chapter Eight: Concession to [the Parents'] Will } \\
\text { 體志章第八 }\end{array}$ \\
\hline & $\begin{array}{l}\text { Chapter Nine: Elucidating the Way [of Virtue] } \\
\text { 諭道章第九 }\end{array}$ \\
\hline & $\begin{array}{l}\text { Chapter Ten: Fulfilling Filial Piety } \\
\text { 盡孝章第十 }\end{array}$ \\
\hline & $\begin{array}{l}\text { Chapter Eleven: Cherishing the Days } \\
\text { 愛日章第十一 }\end{array}$ \\
\hline
\end{tabular}

39 See the postscript at the end of the book, Xingtian zhenjing, 1837 edition, $b a$ 跋, 1b-2a. 


\begin{tabular}{l|l}
\hline Original edition & Qiqu edition \\
\hline \multirow{4}{*}{$\begin{array}{l}\text { Chapter Three: Distinguishing Filial Piety } \\
\text { 辨孝章第三 }\end{array}$} & $\begin{array}{l}\text { Chapter Twelve: Distinguishing Filial Piety } \\
\text { 辨孝章第十二 }\end{array}$ \\
\cline { 2 - 2 } & $\begin{array}{l}\text { Chapter Thirteen: Putting forward from One Instance } \\
\text { 推行章第十三 }\end{array}$ \\
\cline { 2 - 2 } & $\begin{array}{l}\text { Chapter Fourteen: Invariable Nature } \\
\text { 恒性章第十四 }\end{array}$ \\
\hline $\begin{array}{l}\text { Chapter Four: Guarding the Body } \\
\text { 守身章第四 }\end{array}$ & $\begin{array}{l}\text { Chapter Fifteen: Guarding the Body } \\
\text { 守身章第十五 }\end{array}$ \\
\hline Chapter Five: Teaching Filial Piety & $\begin{array}{l}\text { Chapter Sixteen: Teaching Filial Piety } \\
\text { 教孝章第十六孝章第五 }\end{array}$ \\
\hline \multirow{4}{*}{$\begin{array}{l}\text { Chapter Six: Action [and Retribution] of Filial } \\
\text { Piety }\end{array}$} & $\begin{array}{l}\text { Chapter Seventeen: Action [and Retribution] } \\
\text { of Filial Piety } \\
\text { 孝感章第立章第十七 }\end{array}$ \\
\cline { 2 - 2 } & $\begin{array}{l}\text { Chapter Eighteen: Valuing the Precepts } \\
\text { 重戒章第十八 }\end{array}$ \\
\hline
\end{tabular}

We can also learn from the postscript that the word 'old' in the title of the Qiqu edition has a theological significance. The Qiqu edition was called 'old' only because, according to Wenchang's revelation through spirit-writing in 1735 , the deity insisted that this eighteen-chapter version was the authentic version of the Scripture, while the edition in six chapters was a human creation that included offensive content of Buddhist nature. In other words, the word 'old' denotes that Huang Zhengyuan's spirit-writing edition 'recovered' the 'authentic' form of the Scripture.

The Qiqu edition displays eighteen chapters. This was not an arbitrary choice. It met the number of chapters of the Classic of Filial Piety. In a preface of the Qiqu edition revealed by Wenchang through spirit-writing in 1737 , the deity pointed explicitly that

when I was on Mount Qiqu, I imitated the Former Sage's [i.e., Confucius] intention when he instructed Zengzi and compiled the Scripture of Filial Piety in eighteen chapters. The ignorant men did not see it clearly and rearranged [its contents] into six chapters. In addition, they inserted gāthās, hymns, and incantations, making its pages full of the sounds from the western Sanskrit songs; this caused scholars to despise it as if it were one of Gautama's books. Closing the book, scholars would not read it. I extremely hate this [edition in six chapters]! ${ }^{40}$

予昔在七曲, 彷先聖告曾子之意, 作《孝經》十八章。昧者不察, 改為六則, 且 贅以偈頌贊咒, 滿紙皆西方梵唄之音, 以致學者薄為賉昙之書, 掩卷不觀。予甚 恨焉。

In order to emphasise the Confucian nature of the Scripture, Huang Zhengyuan attached Confucian sayings about filial piety to his Qiqu edition. The resulting book was entitled 'True Realm of Nature and Heaven', which followed Wenchang's requirement through spirit-writing.

It is equally noteworthy that Huang modified the plain text as well. More specifically, he deleted not only the incantations, gāthās, and hymns but also some particular sentences, especially

40 See the revealed preface included at the beginning of the book, Xingtian zhenjing, 1837 edition, $x u$ 序, 1b-2a. 
those related to Daoism and Buddhism. The removed elements included but were not limited to 1) deities and spiritual entities, such as the 'Three Corpses' (sanshi 三尸) and Yamaräja (Yanluo 閻羅); 2) transcendent realms, such as 'World of Unproudness' (bujiao jing 不䣖境) and 'ThirtySix Heavens' (sanshiliu tian 三十六天); 3) Samsāra or reincarnation such as 'Four Kinds of Birth and Six Destinies' (sisheng liudao 四生六道) and Preta (e'gui 餓鬼). In one particular case, Huang replaced the 'Heavenly God in the Grand Veil (Heaven)' (daluo tianshen 大羅天神) with 'High Emperor, the August One' (huang yi shangdi 皇矣上帝). Both could refer to the highest deity, while the latter could be found in the Classic of Poetry (Shijing 詩經), one of the earliest Classics within the Confucian tradition, and the former usually used in a Daoist context. ${ }^{41}$ And unlike Lü Weiqi, Huang despised both Daoism and Buddhism, so that he tried to transform the Scripture into a 'pure' Confucian text, even though the text originally combined elements from the three traditions.

\subsection{The Perfected Scripture of Ample Transformation}

The last variant of the Scripture was produced in a spirit-writing altar dedicated to Lüzu, rather than Wenchang. This variant was renamed the Perfected Scripture of Ample Transformation (Guanghua zhenjing 廣化真經, hereafter Ample Transformation). Its earliest edition was included in the Complete Works of Lüzu (Lüzu quanshu 呂祖全書), compiled in 1775 (Qianlong 40). ${ }^{42}$ Shao Zhilin 邵志琳, one of the main compilers of the Complete Works of Lüzu, claimed that

The Ample Transformation is based on a printed edition published by the Wus from Suzhou; it is a revision of the Scripture of Filial Piety, carried out by the Perfected Man Liu. Inside, [the scripture] displays the two original prefaces by Qiu and Wang. Considering that this scripture is a revised edition, it seems proper to remove [these two prefaces]. ${ }^{43}$

《廣化真經》，出蘇城吳氏刻本，系柳真人改定《孝經》。內列邱王原序二篇， 但經既改本，似可刪去。

Therefore, the source-edition of this edition was published in the Jiangnan area. And the so-called 'two original prefaces by Qiu and Wang' must refer to the paratexts attributed to Qiu Jun and Wang Ao in the Scripture. Undoubtedly the Ample Transformation was a revision based on the original Scripture in six chapters. The name Perfected Liu refers to Liu Qi 柳棨, also known as the Perfected Lord Who Promulgates the Teachings (Hongjiao zhenjun 宏教真君). This god was worshipped in many spirit-writing altars dedicated to Lüzu and regarded as the very first disciple of the latter. In fact, most of the literati communities that compiled editions of the Complete Works of Lüzu worshipped the Perfected Liu (Lai 2015).

This edition includes several paratexts, including: (1) one preface ( $x u$ 序) and (2) one postface (houxu 後序) by the Perfected Liu; (3) one postscript ( $b a$ 咙) by the Tranquil One on the South of

41 The Grand Veil Heaven appeared first in the early medieval Daoist scriptures (Bokenkamp 1997: 382-384) and became a simple name of the highest realm in the Daoist tradition. The High Emperor is one of the earliest high deities in Chinese history; for its identity, see Allan 2007; on the religions in early China, see Lagerwey and Kalinowski 2009.

${ }^{42}$ Lüzu quanshu, 1775 edition, volume 56. On the different editions of the Lüzu canons, see Lai 2013.

43 Lüzu quanshu, 1775 edition, fanli 凡例, $5 \mathrm{a}$. 
the Water (shuinan jingzhe 水南靜者); ${ }^{44}$ (4) and one postscript by Cheng Jiazheng 程嘉政 from Suzhou. The former three paratexts are received through spirit-writing but bear no dates. The postscript, however, mentions that the book was finished in 1743 (Qianlong 8). The signature in small characters next to the book title indicates that the plain text was 'revised by the Perfected Liu following the mandate given by the Divine Lord of Wenchang in Qianlong 7 (1742)'. After the plain text of the Scripture, one finds texts exhorting filial piety. These texts, most of which received through spirit-writing in 1743, were revealed by Lüzu, Wenchang, Guandi, etc.. In other words, the plain text of the Ample Transformation was accomplished in 1742, while the whole book, including all the appendixes, was finished in 1743. Besides, Cheng Jiazheng's postscript was dated 1772 (Qianlong 37), which implies that his reprint was probably one of the sources of the Complete Works of Lüzu.

The preface revealed by the Perfected Liu specifies that it was the Divine Lord of Wenchang himself who endowed him with the authority to revise the Scripture as a new edition, i.e., the Ample Transformation. Unlike the Qiqu edition, the Ample Transformation does not alter the Scripture's original structure but its rhetoric and writing style: vernacular expressions were changed into classic ones, ${ }^{45}$ while some redundant sentences were removed. Besides, most of the gāthās and incantations were deleted as well. ${ }^{46}$ The preface claims that Wenchang had regretted having written the Scripture in a vernacular style, causing the literati to despise it. That is why Wenchang authorised the Perfected Liu to revise it into a more elegant version. This revised edition shows that some literati communities at that time were discontent with the vernacular style of the transmitted edition of the Scripture and attempted to improve its literary features.

\section{REPRINTS AND COMMENTARIES}

In this section, I will introduce the different editions of the three variants briefly. It is impossible to describe all the extant editions of the Scripture. Suffice it to say that many of them were published as elementary education textbooks for reading or circulated as morality books used in order to accumulate good merits. ${ }^{47}$ I will not discuss those kinds of editions in detail. I will rather devote my attention to more exceptional editions, such as those editions with commentaries or specific information about their historical contexts.

\footnotetext{
44 This immortal was not mentioned elsewhere. It could be the deified Chen Ting 陳霆 (fl. 1502-1506), whose anthology was entitled Shuinan $j i$ 水南集.

45 For example, the sentence '[children] will not be delivered before ten months [of pregnancy, and they] stay in their mother's [womb as a] fetus. When the mother exhales, they exhale; when the mother inhales, they inhale (十 月未生, 在母胎中; 母呼亦呼, 母吸亦吸)' in the original edition was changed into 'during the ten months of pregnancy, [the child and the mother] share the same breath [, sentiments, and fates] (懷胎十月, 呼吸相通)' in the Ample Transformation.

46 But the last two gāthās were preserved with new titles, in which the character ji 偈 for 'gāthä' changed into $s h i$ 詩 for 'poem'. As I mentioned above, all the gāthās and incantations scattered in the plain texts were actually vernacular poems.

47 For the general study on the practice to accumulate good merits and diminish demerits in late imperial China, see Brokaw 1991.
} 


\subsection{The original Scripture and its reprints}

In addition to the two editions of the New Commentaries mentioned above (i.e., the Kyoto and the Beijing editions), the Scripture also had other special and commented versions.

Another important eighteen-century edition is the Collection of the Classic and Scripture of Filial Piety (Xiaojing heke 孝經合刻), published by Li Fengcai 李鳳彩 in 1784 (Qianlong 49). The word 'collection' in its title refers to the combination of the Scripture and the Classic of Filial Piety. Therefore, it was also entitled 'Collection of the Scriptures of Filial Piety of Confucius and Wenchang' (Kongzi Wenchang xiaojing heke 孔子文昌孝經合刻) or 'Collection of the Scriptures of Filial Piety of Kong and Wen' (Kong Wen xiaojing heke 孔文孝經合刻). This edition does not record the paratexts attributed to Qiu Jun and Wang Ao. In his preface, however, Li Fengcai mentions these two paratexts, which means that they were probably removed intentionally. Li may have wanted to remove the Scripture from its historical framework so that it could be perceived as a sacred text with a status similar to the Classic of Filial Piety. It is also worth mentioning that $\mathrm{Li}$ attached several religious tracts revealed by Guandi and some miracle tales (lingying gush $i$ 靈 應故事) related to the Scripture as an appendix, which implies that his edition was designed as a morality book. ${ }^{48}$

The Extended Meanings of the Scripture of Filial Piety of Wenchang (Wenchang xiaojing yanyi 文昌孝經衍義) is another commented edition besides the New Commentaries. It was published in 1815 (Jiaqing 20). According to Guo Hongben's 郭宏本 preface, the source-edition of the book was the Anthology mentioned above. He published this commentary due to the fact that there were many commented editions of the Hidden Administration, while very few scholars produced commentaries to the Scripture.

The mid-late Qing dynasty also bore witness to the formation of a commentary attributed to Qiu Jun. In other words, one preface within the Scripture was attributed to Qiu Jun at first in the late Ming or early Qing, and some commentaries were further attributed to him from the midlate Qing onwards. The earliest extant exemplar I have found was the Scripture of Filial Piety of the Divine Lord of Wenchang (Wenchang dijun xiaojing 文昌帝君孝經), produced in 1870 (Tongzhi 9), and now housed in the Hunan Library. This edition contained a new preface also attributed to Qiu Jun and entitled 'the original preface of Qiu's commentaries' (Qiu zhu yuanxu 邱注原序). The beginning of the book indicates that 'the original commentaries [were authored] by Master Qiu Zhongshen from Qiongshan, the supplemental commentaries [were authored] by Master $\mathrm{Wu}$ Yunzhuang from Tongcheng, the side commentaries [were authored] by Master Xu Ershan from Xiangfu.' ${ }^{\prime 9}$ Accordingly, the plain text was followed by two kinds of commentaries in double lines and small characters (shuanghang xiaozhu 隻行小註), beginning with the character 'Qiu 邱” or 'Wu 吳' , while the third kind of commentaries could be found on the right side of the plain text. The book also included two other paratexts, written by the publisher Zheng Jing 鄭經 and by Zhang Xingshu 張行澍 in 1851 (Xianfeng 1). Zhang mentions in his postscript that the source-edition of the book was compiled by Xu Ershan 徐餌珊 in 1835 (Daoguang 15). If this information is historically accurate, then the commentaries attributed to Qiu and $\mathrm{Wu}$ (or by historical $\mathrm{Wu}$ ) appeared no later than 1851. In other words, there were at least three editions of this

\footnotetext{
48 For a recent discussion on the types and pattern of morality books, see Goossaert 2019.

49 環山邱仲深先生原注, 桐城吳雲莊先生補注, 祥符徐餌珊先生旁注。Wenchang dijun xiaojing, 1870 edition, mulu 目錄, $1 \mathrm{~b}$.
} 
commentary, produced in 1835, 1851, and 1870. In addition to the 1870 exemplar, I also found an 1877 (Guangxu 3) reprint in the Nanjing Library.

Interestingly, the commentary attributed to Qiu could be traced back to another edition. In an 1843 (Daoguang 23) commented edition of the Scripture, which is also housed in the Hunan Library, a postscript by someone named Zhang Dahong 張大鴻 indicates that 'this scripture has original commentaries, but I do not know who their authors are. ${ }^{50}$ By comparing the anonymous commentaries with those attributed to Qiu in the 1870 exemplar, it is not difficult to find that the latter is actually a concise version of the former. Therefore, we had two similar sets of commentaries in the Daoguang reign, an anonymous full version and a short one attributed to Qiu, which helps us to understand the formation process of such attribution.

\subsection{The Qiqu edition and its reprints}

The extant Daoguang edition of True Realm of Nature and Heaven includes the commentaries written by Huang Zhengyuan for the Qiqu edition of the Scripture. They were presented as side commentaries and put on the right side of the commented sentences. If this edition preserves the original form of the first edition published theoretically in 1737, then the Qiqu edition was probably produced along with the commentaries written by Huang.

During the mid-Qing, there appeared several other commentaries of the Qiqu edition. Both the National Library of China and the Waseda University house 1834 (Daoguang 14) exemplars of Wang Deying's 王德摸 (fl. 1814-1818) Commentaries on the Scripture of Filial Piety of Wenchang (Wenchang xiaojing zhu 文昌孝經注). These exemplars are the earliest extant copies of this edition. According to one paratext, Wang Deying published this book as early as 1816 (Jiaqing 21) and republished it in 1821 (Daoguang 1), 1829 (Daoguang 9), and 1834. Under the book title, it is indicated that the book was 'commented by Wang Deying. Nevertheless, the commentaries were actually collected rather than written by Wang. This may be proven by comparison with the other commentaries mentioned above. Wang's book combined several commentaries, variously attributed to Tang Wanghuang, Huang Zhengyuan, and Qiu Jun. ${ }^{51}$ Besides, the Shandong Library houses another 1888 (Guangxu 14) exemplar of Wang's book, and the format and style were identical to the 1834 exemplar, which means that the former could be a reprint or facsimile of the latter.

Another commentary published in a similar time was entitled Commentaries and Statements on the Scripture of Filial Piety of Wenchang (Wenchang xiaojing zhuanyi 文昌孝經傳繹). The author was named Dai Ji 戴楫, and he claimed in the preface that the motivation to publish this book was to pray for healing his mother's illness. He got the revelation from the Divine Lord of Wenchang that he must publish a comment book on the Scripture. The 'commentaries' (zhuan 傳) in the title referred to the philological explanation of the text, and the 'statements' ( $y i$ 繹) referred to argumentative elaborations on scriptural meaning. The book was based on the Qiqu edition rather than the original one, but Huang's commentaries were removed for unknown reasons.

50 是經原有注釋, 不知出自誰手。Wenchang xiaojing, 1843(?) edition, $b a$ 跋, 2a-b.

51 The commentaries by Tang and attributed to Qiu were based on the six-chapter scripture. However, as mentioned above, the eighteen chapters were actually split from the six chapters. Therefore, the commentaries could be easily relocated into the Qiqu edition. 
It is also noteworthy that there is a Korean translation of the Qiqu edition. The Tōyo Bunko houses an exemplar published by Chang Sungsoon 張星淳 from Dansan 丹山, Korea. The book is undated, but by judging from its style, it was probably published in the late nineteenth century. ${ }^{52}$ This bilingual edition only preserves the plain text of the Scripture but not the paratexts or the commentaries.

\subsection{The Ample Transformation and its reprint}

Compared with the other two variants, the Ample Transformation has fewer reprints. The only Qing edition I have ever found beside the original one was the Direct Interpretation on the Scripture of Filial Piety of Wenchang (Wenchang xiaojing zhijie 文昌孝經直解), produced in 1869 (Tongzhi 8). The compilers claimed that they were at first confused by the different variants of the Scripture. Then they received the revelation from Wenchang through spirit-writing and chose the Ample Transformation instead of other variants to comment on and publish as a textbook for elementary education.

\section{CONCLUSION}

According to the examination above, the paratexts attributed to the neo-Confucian scholar-officials Qiu Jun and Wang Ao were spuriously fabricated by later compilers, while the claim in the preface that the Scripture was produced as early as the Song dynasty is also historically inaccurate. The Scripture was produced during the Ming-Qing transition.

The formation and early circulation of the Scripture were deeply influenced by the Confucian texts and Confucian literati's individual practices. The ritualisation of the Classic of Filial Piety also played an important role in the formation and the circulation of the Scripture. The Scripture developed into three different variants, and all of them had their own commentaries and reprints. Confucian literati were the main social actors responsible for the reproduction, revision, and circulation of these editions long before Daoists included the Scripture into the New Edition.

Therefore, it is incorrect to understand the Scripture as an exclusively Daoist text. The Scripture is also the result of a 'Confucian' renovation movement taking place in late imperial China. It witnessed the literati's attempts to ritualise the Classic of Filial Piety and to textualise newly invented rituals during the Ming-Qing transition. They blurred the boundaries between the 'three teachings' (sanjiao 三教, i.e. Confucianism, Daoism, and Buddhism) and created new mediums (rituals) and messages (texts) to produce a new form of authority and identity: a brand new comprehensive Confucianism which could incorporate different traditions. ${ }^{53}$ That also explains the reason why whoever fabricated Qiu Jun's preface coined the famous expression: 'Wenchang is the Confucius from the Anterior Heaven. Confucius is the Wenchang from the Posterior Heaven.' (文昌，先天之孔子；孔子，後天之文昌)

${ }^{52}$ In addition, according to the online catalogue of the Library of Korean Studies, it houses an exemplar with the same title and author name, which was published in 1884. https://lib.aks.ac.kr/search/DetailView.ax?sid=1\&cid $=169541$ (Accessed 22 Aug 2020)

${ }^{53}$ For the relationship between authority and ritualisation, see Bell 1988; 1992: 197-223; for Catherine Bell's insight of focusing on the change and discontinuity aspect of rituals, see Lincoln 2000. 
The editorial history of the Scripture also reflects both the tension between the two self-identifications of Confucianism and Daoism and the compilers' attempts to balance it. In the story of Lü Weiqi, the talismans and registers, which were traditionally regarded as Daoist, became the esoteric knowledge of the Classic of Filial Piety. It is not difficult to imagine that this kind of interpretation was definitely unacceptable to Huang Zhengyuan, who angrily removed all the elements he regarded as Daoist or Buddhist from the Scripture. It is noteworthy that his authority was actually endorsed by the ritual of spirit-writing, and he regarded the descending deity, Wenchang, as a 'Confucian' god rather than a 'Daoist' one. In spite of Huang's efforts, the original version of the Scripture was nevertheless accepted by many Confucian literati throughout the Qing dynasty. In fact, between Lü and Huang, there was another way to balance the different elements of Confucianism and Daoism. In the Complete Works, the most famous and important Wenchang collection produced during the Qing dynasty, the Scripture was included in the 'esoteric case' (neihan 內函) while the talismans and registers attributed to Wenchang were included in the 'exoteric case' (waihan 外函), and both of them constitute the 'Confucian orthodoxy' (rujiao zhengzong 儒教正宗).$^{54}$ I hope this specific study of the Scripture could help us to open a new window to observe and understand the fluctuant boundaries between different religious discourses in late imperial China and remind us, modern scholars, again how fragile or flexible the terms such as 'Confucianism' and 'Daoism' could be when we use them as analytical categories.

\section{REFERENCES}

\section{Primary Sources}

\subsection{The Scripture of Filial Piety [Revealed] by Wenchang and its editions}

Guanghua zhenjing 廣化真經 [Perfected Scripture of Ample Transformation]. Included in Lüzu quanshu 呂 祖全書 [Complete Works of Lüzu], compiled by Liu Qiao 劉樵 (fl. 1727-1749), reedited by Shao Zhilin 邵志琳 (fl. 1775), volume 56. 1775 edition. Housed in the Havard Yenjing Library.

Wenchang dijun xiaojing 文昌帝君孝經 [Scripture of Filial Piety of the Divine Lord of Wenchang]. Compiled by anonymous. 1870 reprint. Housed in the Hunan Library.

Wenchang dijun xiaojing 文昌帝君孝經 [Scripture of Filial Piety of the Divine Lord of Wenchang]. Compiled by Zhang Xingchun 張星淳. 1884 edition. Housed in the Tōyō Bunko.

Wenchang xiaojing yanyi 文昌孝經衍義 [Amplification of the Scripture of Filial Piety of Wenchang]. Commented by Guo Hongben 郭宏本 (fl. 1788-1800). 1815 edition. Housed in the Nanjing Library.

Wenchang xiaojing zhijie 文昌孝經直解 [Direct Interpretation on the Scripture of Filial Piety of Wenchang]. Compiled by anonymous. 1869 edition. Housed in the Nanjing Library.

Wenchang xiaojing zhuanyi 文昌孝經傳繹 [Commentaries and Statements on the Scripture of Filial Piety of Wenchang]. Commented by Dai Ji 戴楫 (fl. 1840). 1840 edition. Housed in the National Library of China.

Wenchang xiaojing 文昌孝經 [Scripture of Filial Piety of Wenchang]. Commented by Tang Wanhuang 湯萬 煌 (fl. 1722). 1738 reprint. Housed in the Kyoto University.

Wenchang xiaojing 文昌孝經 [Scripture of Filial Piety of Wenchang]. Compiled by anonymous. 1877 reprint. Housed in the Nanjing Library.

${ }^{54}$ Wendi quanshu, 1743 edition, $x u$ 序, 2a. 
Wenchang xiaojing 文昌孝經 [Scripture of Filial Piety of Wenchang]. Compiled by anonymous. 1843(?) edition. Housed in the Hunan Library.

Wenchang xiaojing zhu 文昌孝經注 [Commentaries on the Scripture of Filial Piety of Wenchang]. Commented by Wang Deying 王德瑛 (fl. 1814-1818). 1834 reprint. Housed in the National Library of China.

Wenchang xiaojing zhu 文昌孝經注 [Commentaries on the Scripture of Filial Piety of Wenchang]. Commented by Wang Deying 王德瑛 (fl. 1814-1818). 1834 reprint. Housed in the Waseda University.

Wenchang xiaojing zhu 文昌孝經注 [Commentaries on the Scripture of Filial Piety of Wenchang]. Commented by Wang Deying 王德瑛 (fl. 1814-1818). 1888 reprint. Housed in the Shandong Libary.

Wenchang Xiaojing 文昌孝經 [Scripture of Filial Piety of Wenchang]. Collated by Zhu Gui (朱珪, 17311806). Included in the Wendi shuchao 文帝書鈔 [Anthology of the Divine Lord of Wenchang], compiled by Zhu Gui 朱珪 (1731-1806), volume 1. 1795 reprint. Owned by the author.

Wendi xiaojing 文帝孝經 [Scripture of Filial Piety of the Divine Lord of Wenchang]. Collated by Zhu Gui 朱 珪 (1731-1806). Included in the Daozang jiyao 道藏輯要 [Essentials of the Daoist Canon]. Compiled by Jiang Yupu 蔣予蒲 (1755-1819) et al. 1810s edition. Housed in the Sichuan Library.

Wendi xiaojing 文帝孝經 [Scripture of Filial Piety of the Divine Lord of Wenchang]. Collated by Zhu Gui 朱 珪 (1731-1806). Included in the Chongkan daozang jiyao 重刊道藏輯要 [New Edition of the Essentials of the Daoist Canon]. Compiled by He Longxiang 賀龍驤 (fl. 1891-1906) et al. 1900s edition. Housed in the Chinese University of Hong Kong.

Wendi xiaojing 文帝孝經 [Scripture of Filial Piety of the Divine Lord of Wenchang]. Collated by Zhu Gui 朱珪 (1731-1806). Facsimile included in the Zangwai daoshu 藏外道書 4. Chengdu: bashu shushe, 1992-1994.

Xiaojing heke 孝經合刻 [Collection of the Classic and Scripture of Filial Piety]. Compiled by Li Fengcai 李 鳳彩 (fl. 1619-1714). 1784 reprint. Facsimile included in the Siku weishoushu jikan 四庫未收書輯刊 3/9. Beijing: Beijing chubanshe, 2000.

Xiaojing xinzhu 孝經新註 [New Commentaries on the Scripture of Filial Piety of Wenchang]. Included in Wendi quanshu 文帝全書 [Complete Works of the Divine Lord of Wenchang], compiled by Liu Qiao 劉樵 (fl. 1727-1749), volume 5.1743 edition. Housed in the Peking University.

Xingtian zhenjing 性天真境 [True Realm of Nature and Heaven]. Compiled by Huang Zhengyuan 黃正元 (fl. 1713-1758). 1837 reprint. Housed in the National Diet Library of Japan.

Xingtian zhenjing 性天真境 [True Realm of Nature and Heaven]. Compiled by Huang Zhengyuan 黃正元 (fl. 1713-1758). 1837 reprint. Housed in the Bavarian State Library.

Xingtian zhenjing 性天真境 [True Realm of Nature and Heaven]. Compiled by Huang Zhengyuan 黃正元 (fl. 1713-1758). 1837 reprint. Housed in the Australian National Library.

\subsection{Texts in the Ming Daoist Canon}

DZ5 Taishang wuji zongzhen Wenchang dadong xianjing 太上無極總真文昌大洞仙經 [Transcendent Scripture of Great Cavern of Wenchang, the Infinite Lord of All the Perfecteds in the Most High Realm] DZ103 Yuqing wuji zongzhen Wenchang dadong xianjing zhu 玉清無極總真文昌大洞仙經註 [Commentaries on the Transcendent Scripture of Great Cavern of Wenchang, the Infinite Lord of All the Perfecteds in the Jade Clarity Realm]

DZ169 Qinghe neizhuan 清河內傳 [Esoteric Biography of Qinghe]

DZ170 Zitong dijun huashu 梓潼帝君化書 [The Book of Transformation of the Divine Lord of Zitong] 


\subsection{Others}

Mingshi 明史 [History of the Ming]. Compiled by Zhang Tingyu 張廷玉 (1672-1755) et al. Siku quanshu 四 庫全書 edition. Chinese Classic Ancient Books Database (via ERUDITION).

Ming shilu 明實錄 [Veritable Records of the Ming]. Facsimiled and collated by the Institute of History and Philology Academia Sinica. Nangang: Institute of History and Philology Academia Sinica, 1962-1968.

Mingde xiansheng wenji 明德先生文集 [Anthology of Master Mingde]. Compiled by Lü Weiqi 呂維祺 (1587-1641). Facsimile included in the Siku quanshu cunmu congshu jibu 四庫全書存目叢書(集部) volume 185. Jinan: qilu shushe, 1997.

Nanyun laoren ziding nianpu 南畍老人自訂年譜 [Self-Corrected Chronological Autobiography of the Old Man Nanyun]. Compiled by Peng Dingqiu 彭定求 (1645-1719). Included in the Changzhou Peng shi jia ji 長洲彭氏家集 [Family Anthology of the Peng Clan of Changzhou], edited by Peng Zuxian 彭祖 賢 (1819-1885). 1881 edition. Housed in the National Library of China.

Nanyun wengao 南畍文稿 [Prose Anthology of Nanyun]. Compiled by Peng Dingqiu 彭定求 (1645-1719). Included in the Changzhou Peng shi jia ji 長洲彭氏家集 [Family Anthology of the Peng Clan of Changzhou], edited by Peng Zuxian 彭祖賢 (1819-1885). 1881 edition. Housed in the National Library of China.

Tianzhong xuzi zhengxue heyi ji 天中許子政學合一集 [Anthology on the Unity of the Politics and Education by Master Xu at the Centre of the Heaven]. Compiled by Xu Sanli 許三禮 (1625-1691). Facsimile included in the Siku quanshu cunmu congshu zibu 四庫全書存目叢書(子部) volume 165. Jinan: qilu shushe, 1997.

Wangxi ji 望溪集 [Anthology of Wangxi]. Compiled by Fang Bao 方苍 (1668-1749). 1851 edition. Housed in the Shanghai Library.

Xiaojing huowen 孝經或問 [Interlocution on the Classic of Filial Piety]. Compiled by Lü Weiqi 呂維祺 (1587-1641). Facsimile included in the Xuxiu siku quanshu 續修四庫全書 volume 151. Shanghai: Shanghai guji chubanshe, 2002.

\section{Secondary Sources}

Allan, Sarah 2007.'On the Identity of Shang Di 上帝 and the Origin of the Concept of a Celestial Mandate (Tian Ming 天命).' Early China 31: 1-46.

BeLL, Catherine 1988. 'Ritualization of Texts and Textualization of Ritual in the Codification of Taoist Liturgy.' History of Religions 27/4: 366-392.

BeLl, Catherine 1992. Ritual Theory, Ritual Practice. New York: Oxford University Press.

Bokenkamp, Stephen 1997. Early Daoist Scriptures. Berkeley \& Los Angeles \& London: University of California Press.

Brokaw, Cynthia J. 1991. The Ledgers of Merit and Demerit. Social Change and Moral Order in Late Imperial China. Princeton: Princeton University Press.

Burton-Rose, Daniel 2020. 'Establishing a Literati Spirit-Writing Altar in Early Qing Suzhou: The Optimus Prophecy of Peng Dingqiu (1645-1719).' T'oung Pao 106: 358-400.

Esposito, Monica 2007. 'The Discovery of Jiang Yuanting's Daozang jiyao in Jiangnan: A Presentation of the Daoist Canon of the Qing Dynasty.' In: Mugitani Kunio 麥谷邦夫 (ed.) Kōnan dōkyō no kenkyū 江南道教の研究 [A study on Daoism in the Jiangnan area]. Kyoto: Jinbun Kagaku Kenkyūjo, 79-110.

Esposito, Monica 2009. 'The Daozang Jiyao Project: Mutations of a Canon.' Daoism: Religion, History and Society 1: 95-153. 
Esposito, Monica 2013. 'The Invention of a Quanzhen Canon: The Wondrous Fate of the Daozang jiyao' In: Vincent Goossaert and Liu Xun (eds.) Quanzhen Daoism in Modern Society and Culture. Berkeley: Institute of East Asian Studies, 44-77.

GAO Wu 高梧 2008. Wenchang xinyang xisu yanjiu 文昌信仰習俗研究 [A study on the customs of the Wenchang cult]. Chengdu: Bashu shushe.

Goossaert, Vincent 2012. Livres de Morale Révélés par les Dieux. Paris: Belles-Lettres.

Goossaert, Vincent 2014. 'Modern Daoist Eschatology: Spirit-Writing and Elite Soteriology in Late Imperial China.' Daoism: Religion, History and Society 6: 219-246.

Goossaert, Vincent 2015. 'Spirit Writing, Canonization, and the Rise of Divine Saviors: Wenchang, Lüzu, and Guandi, 1700-1858.' Late Imperial China 36/2: 82-125.

Goossaert, Vincent 2019. 'Late Imperial Chinese Piety Books.' Studies in Chinese Religions 5/1: 38-54.

HsieH Tsung-hui 謝聰輝 2013. Xin tiandi zhi ming: yuhuang, zitong yu feiluan 新天帝之命:玉皇、梓潼與 飛鸞 [Mandate from the New Heavenly Emperor: Jade Sovereign, Zitong, and Flying Phoenix]. Taiwan: Commercial Press.

Hu Jiechen 胡劼辰 2020. 'Qingdai liuzhong wendi lei quanshu de chuban shi yanjiu 清代六種文帝類全書 的出版史研究 [A Historical Investigation into the Publication in the Qing Dynasty of the Wenchang Canons in Six Varieties].' Bulletin of the Institute of History and Philology Academia Sinica 91/2: 227-292.

Hu Jiechen 胡劼辰 2016. “Wenchang dijun yinzhiwen” qiyuan xinyan 《文昌帝君陰览文》起源新研 [A new study on the origin of the Wenchang dijun yinzhi wen].' In: Li Shiwei 李世偉 (ed.) Lishi, yishu yu Taiwan renwen luncong (shiyi) 歷史、藝術與臺灣人文論叢（十一） [Journal of History, Art, and Taiwan Humanities 11]. Xinbei: Boyang wenhua, 133-169.

Hucker, Charles O. 1985. A Dictionary of Official Titles in Imperial China. Stanford: Stanford University Press.

Jones, Lindsay (ed.) 2005. Encyclopedia of Religion: Second Edition. Farmington Hills: Thomson Gale.

KAKIUCHI Tomoyuki 垣内智之 and IKeHIRA Noriko 池平紀子 2012. 'Dōzō shuyō hanpon kō 道蔵輯要 版本考 [A bibliographical study on the editions of the Daozang jiyao]. In: Mugitani Kunio 麥谷邦 夫 (ed.) 'Dōzō shuyō’ to Mei-Shin jidai no shūkyō bunka 《道蔵輯要》と明清時代の宗教文化 [The Daozang jiyao and the religious culture of the Ming and Qing eras]. Kyoto: Jinbun Kagaku Kenkyūjo, 271-443.

KIM, Jihyun 2015. 'The Invention of Traditions: With a Focus on Innovations in the Scripture of the Great Cavern in Ming-Qing Daoism.' Daoism: Religion, History and Society 7: 63-115.

Kleeman, Terry L. 1993. 'The Expansion of the Wenchang Cult'. In: Patricia B. Ebrey and Peter N. Gregory (eds.) Religion and Society in T'ang and Sung China. Honolulu: University of Hawai'i Press, 45-73.

Kleeman, Terry L. 1994. A God's Own Tale: The Book of Transformations of Wenchang, the Divine Lord of Zitong. New York: State University of New York Press.

Kleeman, Terry L. 1996. 'The Lives and Teachings of the Divine Lord of Zitong.' In: Donald S. Lopez Jr. (ed.) Religions of China in Practice. Princeton, N.J.: Princeton University Press, 64-71.

LAI Chi-tim 黎志添 2013. 'Qingdai sizhong “Lüzu quanshu” yu Lüzu fuji daotan de guanxi 清代四種《呂 祖全書》與呂祖扶乩道壇的關係 [The Four Compilations of Lüzu quanshu and Daoist Spirit-Writing Altars in the Qing Period].' Bulletin of the Institute of Chinese Literature and Philosophy 42: 183-230.

LAI Chi-tim 黎志添 2015. “Lüzu quanshu zhengzong”: Qingdai Beijing jueyuan tan de lishi ji qi Lüzu tianxian pai xinyang 《吕祖全書正宗》：清代北京覺源壇的歷史及其呂祖天仙派信仰 [The Lüzu quanshu zhengzong: The History of the Jueyuan Altar of Beijing and the Cult of its Lüzu Tianxian Lineage during the Qing Dynasty].' Bulletin of the Institute of Chinese Literature and Philosophy 46: $101-149$. 
LAI Chi-tim 黎志添 (ed.) 2021. Daozang jiyao tiyao 道藏輯要・提要 [A companion of the Daozang jiyao]. Hongkong: Chinese University of Hong Kong Press.

LAN Yonghui 監永輝 2011. “Wenchang xiaojing” yu “Xiaojing” zhi bijiao《文昌孝經》與《孝經》之比 較 [A comparative study between the Wenchang xiaojing and the Xiaojing].' In: JING Yongjing 敬永金 et al. (ed.) Zhonghua Wenchang wenhua 中華文昌文化 [The Wenchang culture in China]. Conference proceedings, 115-124.

Lagerwey, John and Marc Kalinowski (eds.) 2009. Early Chinese Religion, Part One: Shang through Han (1250 BC - 220 AD). Leiden \& Boston: Brill.

LEE Cheuk-yin 李焯然 2005. Qiujun pingzhuan 丘爘評傳 [Critical biography of Qiu Jun]. Nanjing: Nanjing University Press.

Lincoln, Bruce 2000. 'On Ritual, Change, and Marked Categories.' Journal of the American of Religion 68/3: 487-510.

Lu Miaw-fen 呂妙芬 2005. “Wanming “Xiaojing” lunshu de zongjiao xing yihan: Yu Chunxi de xiaolun ji qi wenhua mailuo 晚明《孝經》論述的宗教性意涵：虞淳熙的孝論及其文化脈絡 [Religious Dimensions of Filial Piety Developed during the Late Ming: Yu Chunxi's Interpretation of the Xiaojing and Its Cultural Context]. Bulletin of the Institute of Modern History Academia Sinica 48: 1-46.

Lu Miaw-fen 呂妙芬 2008. 'Zuowei yishi xing wenben de “Xiaojing”: Ming-Qing shiren “Xiaojing” shijian de ge’an yanjiu 做為儀式性文本的《孝經》：明清士人 《孝經》實踐的個案研究 [The Classic of Filial Piety as a Ritual Text: Case Studies on the Practice of Ming-Qing Confucian Scholars].' Bulletin of the Institute of Modern History Academia Sinica 60: 1-42.

Lu Miaw-fen 呂妙芬 2011. Xiao zhi tianxia: “Xiaojing” yu jinshi Zhongguo de zhengzhi yu wenhua 孝治天 下：《孝經》與近世中國的政治與文化 [Governing the world with filial piety: the Classic of Filial Piety and the politics and culture of late imperial and modern China]. Taibei: Lianjing chubanshe.

MaruYama Hiroshi 丸山宏 2015. 'Qingchao daoguang nian jian Jingai shan Lüzu daotan suo chuangzao zhi jingdian chutan: yi "Yuqing zanhua jiutian yanzheng xinyin jijing", "Yuqing zanhua jiutian yanzheng xinyin baochan” wei zhongxin zhi tantao 清朝道光年間金蓋山呂祖道壇所創造之經典初探：以 《玉清化九天演政心印集經》、《玉清贊化九天演政心印寶懺》為中心之探討 [A Preliminary Study on Two New Scriptures Invented at Daoist Altar of Mt. Jingai during Daoguang Period of Qing Dynasty: Centering on the Yuqing zanhua jiutian yanzheng xinyin jijing, and the Yuqing zanhua jiutian yanzheng xinyin baochan].' Daoism: Religion, History and Society 7: 171-200.

MoRI Yuria 森由利亞 2001. 'Dōzō shūyō to Shō Yobu no Ryoso fukei shinkō 道藏輯要と蔣予蒲の吕祖 扶乩信仰 [Daozang jiyao and the Jiang Yupu’s Belief of Spirit-Writing of Lüzu].' Tōhō shūkyō 東方宗 教 98: 33-52.

MoRita Kenji 森田憲司 1984. 'Bunshō teikun no seiritsu: chihōshin kara kakyo no kami e 文昌帝君の成 立一一地方神から科挙の神へ [The formation of the Divine Lord of Wenchang: from a local deity to the god of state civil examination].' In: UmeHARA Kaoru 梅原郁 (ed.) Chügoku kinsei no toshi to bunka 中國近世の都市と文化 [City and culture of Modern China]. Kyoto: Kyōto Daigaku Jinbun Kagaku Kenkyūjo, 389-418.

SAKAI Tadao 酒井忠夫 1957. 'Inshitsubun no seiritsu ni tsuite 陰隲文の成立について [About the formation of the Yinzhiwen].' Tōhō shūkyō 東方宗教 7: 1-13.

SAKAI Tadao 酒井忠夫 1999-2000. Zōhō Chūgoku zensho no kenkyū 増補中国善書の研究 [A Study on the Chinese Morality Book: A Supplementary Edition]. Tokyo: Kokusho Kankōkai.

SCHACHTER, Bony 2014. 'Gaoshang Yuhuang benxing jijing (Combined Scriptures of the Original Acts of the Exalted and Superior Jade Sovereign): An Annotated Translation and Study of Its First Chapter.' Monumenta Serica 62: 153-212. 
Schachter, Bony 2015. 'Beyond the Kingly Metaphor: A Sociological Reading of the Scripture of the Jade Sovereign.' Journal of Chinese Studies 60: 95-158.

Schachter, Bony 2018. 'Printing the Dao: Master Zhou Xuanzhen, the Editorial History of the Jade Slips of Great Clarity and Ming Quanzhen Identity'. Daoism: Religion, History and Society 10: 1-86.

Schipper, Kristofer M. and Franciscus Verellen (eds.) 2004. The Taoist Canon: A Historical Companion to the Daozang. Chicago and London: The University of Chicago Press.

WANG Fan-sen 王汎森 1998. 'Mingmo Qingchu ruxue de zongiiao hua 明末清初儒學的宗教化 [The Religious Transformation of Confucianism in Late Ming and Early Qing Thought]. Xin shi xue 新史學 9/2: 89-123.

Wen Zhihua 文志華 2007. You Tong shiji zhenglüe 尤侗事蹟征略 [The Chronicle Biography of You Tong]. (Master diss., Guangxi Normal University)

XIAO Qunzhong 肖群忠 1997. “Wenchang xiaojing” de daojiao xiaodao guan 《文昌孝經》的道教孝道 觀 [The Daoist perspective on the Filial Piety in the Wenchang xiaojing].' Daode yu Wenming 道德與 文明 1997/6: 16-19.

YAU Chi-on 游子安 2005. Shan yu ren tong: Ming-Qing yilai de cishan yu jiaohua 善與人同 : 明清以來的 慈善與教化 [Regarding the goodness of others to be the same as oneself: the philanthropy and teaching since Ming and Qing]. Beijing: Zhonghua shuju.

ZHAN Shichuang 詹石窗 and Li Ji 李冀 2017. 'Wenchang xinyang yu xiaodao chuanbo ji qi shehui liaozhi 文昌信仰與孝道傳播及其社會療治 [Wenchang cult, the transimission of the ways of Filial Piety, and its social cure].' Shijie zongjiao yanjiu 世界宗教研究 2017/1: 104-115.

Open Access. This is an open-access article distributed under the terms of the Creative Commons Attribution-NonCommercial 4.0 International License (https://creativecommons.org/licenses/by-nc/4.0/), which permits unrestricted use, distribution, and reproduction in any medium for non-commercial purposes, provided the original author and source are credited, a link to the CC License is provided, and changes - if any are indicated. 